\title{
KEBIJAKAN PARKIR KOTA BATAM DALAM MENINGKATKAN PENDAPATAN ASLI DAERAH
}

\author{
Riko Riyanda, Timbul Dompak \\ Fakultas Sosial Dan Humaniora Universitas Putera Batam, Batam, Kepulauan Riau \\ email: riyanda.fisip@gmail.com
}

\begin{abstract}
The growth rate of motor vehicles in Batam City in recent years runs very rapidly. This levy will increase the original revenue of Batam City, But the implementation of the policy of Bylaw No.1 / 2012 on parking that has been running for three years (2012-2015) does not generate significant revenue on parking charges. The Purpose of this research is how the implementationn of parking management system based on evaluation of the policy of Bylaw No.1 / 2012 on parking Btam City. Data retrieval method is done by observation and documentation. Informant selection technique is done by purposive sampling, technical data analysis is done by data reduction, data presentation and conclusion drawing. The result of the research is that the policy of Batam City Government in increasing its achievement PAD not yet optimal, due to some obstacles such as: parking management system is not feasible, there is no public satisfaction survey index to measure the extent to which the achievement of parking policy in Batam City, Human Power that needs coaching and training. Its solution of Batan City government refiled Ranpeda about parking with the intention of changing parking rates, changing the system of parking management and service facility improvement
\end{abstract}

Keywords: Parking, Local Regulation No. 1 Year 2012, Local Revenue

\begin{abstract}
Abstrak
Dengan semakin meningkatkan jumlah kendaraan bermotor dari tahun ke tahun di Kota Batam, lahan parkir tentu menjadi perhatian oleh Pemerintah Kota Batam. Penataan lahan parkir tersebut maka akan ada retribusi yang dapat ditarik dari penggunaan lahan parkir. Retribusi ini akan menambah PAD Kota Batam, namun dari implementasi kebijakan Perda No.1/2012 tentang perpakiran yang telah berjalan selama tiga tahun (2012-2015) tidak menghasilkan pendapatan yang signifikan atas retribusi parkir tersebut. Tujuan dari penelitian ini adalah bagaimana pelaksanaan sistem pengelolaan parkir berdasarkan evaluasi perda nomor 1 tahun 2012 tentang parkir di Kota Batam. Tipe penelitian yang digunakan adalah kualitatif, metode pengambilan data dilakukan dengan cara observasi dan dokumentasi. Teknik pengumpulan data dilakukan dengan purposive sampling, teknis analisis datanya reduksi data, penyajian data dan penarik kesimpulan. Hasil penelitian yang diperoleh adalah kebijakan pemerintah Kota Batam dalam meningkatkan PAD pencapaiannya belum optimal, kendalanya adalah: belum adanya indeks survei kepuasan publik untuk mengukur sampai sejauh mana pencapaian kebijakan parkir di Kota Batam, persoalan Sumber Daya Manusia yang perlu pembinaan dan pelatihan. Solusinya perlu adanya perubahan Ranpeda tentang parkir dengan maksud merubah tarif parkir, merubah sistem tentang pengelolaan parkir dan perbaikan fasilitas pelayanan
\end{abstract}

Kata Kunci : Parkir, Perda Nomor 1 Tahun 2012, PAD

\section{PENDAHULUAN}

Data dari Badan Pusat Statistik Kota Batam menyebutkan bahwa jumlah kendaraan roda dua mencapai 216.248 unit dan kendaraan roda empat mencapai 413.986 unit. Dengan semakin meningkatnya jumlah kendaraan bermotor dari tahun ke tahun di Kota Batam, lahan parkir tentu menjadi pusat perhatian oleh Pemerintah Kota Batam. Kebutuhan akan lahan parkir semakin lama terus meningkat, membuat 
Pemerintah kota Batam harus menyediakan lahan parkir yang memadai agar dapat menampung semua aktifitas dari kendaraan bermotor yang ada di Kota Batam (Pratama, 2015). Dengan adanya penyediaan lahan parkir oleh Pemerintah Kota Batam maka akan menambah Pendapatan Asli Daerah Kota (PAD) Kota Batam dari retribusi parkir. Menurut (Samudra, 1995), retribusi adalah pungutan daerah sebagai pembayaran pemakaian atau karena jasa yang diberikan daerah. Menurut Davey retribusi adalah pembayaran langsung oleh mereka yang menikmati pelayanan yang disediakan Pemerintah dan dimaksudkan untuk menutup seluruh atau sebagian dari biaya pelayanannya. (Davey, 1988) Berdasarkan Peraturan Daerah Nomor 1 tahun 2012 tentang kenaikan tarif retribusi parkir serta kebijakan parkir berlangganan di Kota Batam, diharapkan dapat meningkatkan Pendapatan Asli Daerah Kota Batam dari Retribusi Parkir dan juga bertujuan untuk menertibkan kendaraan yang Parkir di tepi jalan umum di Kota Batam. Berikut tabel target dan realisasi penerimaan retribusi parkir di Kota Batam.

Tabel 1. Target dan Realisasi Penerimaan Parkir di Kota Batam

\begin{tabular}{|c|c|c|c|c|}
\hline TAHUN & TARGET & REALISASI & SURPLUS/MINUS & PERSENTASE \\
\hline 2011 & 1.400 .000 .000 & 1.400 .000 .000 & 0 & $100 \%$ \\
\hline 2012 & 5.261 .350 .000 & 3.428 .414 .000 & -1.832 .936 .000 & $(65,2 \%)$ \\
\hline 2013 & 4.500 .000 .000 & 3.296 .835 .400 & -1.203 .164 .600 & $(73,3 \%)$ \\
\hline 2014 & 3.312 .000 .000 & 3.594 .001 .600 & 282.001 .600 & $108,5 \%$ \\
\hline
\end{tabular}

Sumber: Pratama (2015)

Berdasarkan tebel di atas dapat dilihat bahwa penyerapan retribusi parkir masih belum optimal dan belum menyumbangkan secara signifikan kepada PAD Kota Batam. Terkait dengan retribusi parkir yang telah berjalan selama tiga tahun (2012-2015) tidak berbanding lurus dengan pendapatan atas retribusi parkir tersebut. Penyerapan retribusi parkir untuk mendukung PAD Kota Batam masih belum optimal. Jika dilihat dari penjelasan sebelumnya bahwa jumlah kepemilikan kendaraan bermotor dari masyarakat Kota Batam mencapai ratusan ribu baik roda dua maupun roda empat. Jika kepemilikan kendaraan roda dua sebanyak 216.248 unit dikalikan dengan Rp. 1000,- maka total retribusi parkir sehari bisa mencapai 216.248.000 dikalikan 30 menjadi 6.487.440.000 dikalikan 12 maka setahun retribusi parkir hanya dari kendaraan roda dua menembus angka 77.849.280.000. Sedangkan untuk kendaraan roda empat mencapai 413.986 unit dikalikan Rp.2000,- yakni 827.972.000 sehari. Sebulan 24.839.160.000 dan setahun adalah 298.069.920.000. Total pendapat retribusi setahun baik roda dua maupun roda empat adalah 375.919.200.000. Jumlah ini belum termasuk dari bus/truk yang sekali parkir membayar Rp. 3000,-. Lebih lanjut bahwa, retribusi parkir berlangganan juga belum berjalan secara optimal. Bisa kita lihat bahwa masih banyak masyarakat di Kota Batam yang tidak memakai parkir berlangganan padahal dengan parkir berlangganan maka akan dengan mudah pemerintah menghitung jumlah PAD yang disumbangkan dari retribusi parkir. Berdasarkan hal ini, maka akan sangat menarik jika dilakukan kajian terkait "Evaluasi Kebijakan Peraturan Daerah Nomor 1 Tahun 2012 Tentang Parkir di Kota Batam" dengan harapan kajian ini nantinya dapat memberikan sumbangsih baik kesimpulan maupun saran yang dapat digunakan oleh pihak-pihak terkait.

Tulisan ini bertujuan untuk mendeskripsikan dan menganalisis evaluasi kebijakan perpakiran di Kota Batam berdasarkan kebijakan peraturan daerah Nomor 1 Tahun 2012 Tentang Parkir Kota Batam dan menganalisis faktor penghambat dalam pelaksanaan parkir di Kota Batam dalam meningkatkan Pendapatan Asli Daerah. 


\section{METODE}

Penelitian ini menggunakan deskriptif kualitatif. Penelitian deskriptif kualitatif adalah salah satu metode untuk mendapatkan kebenaran dan tergolong sebagai penelitian ilmiah yang dibangun atas dasar teori-teori yang berkembang dari penelitian dan terkontrol atas dasar empirik. Metode penelitian yang dilakukan adalah deskriptif dengan pendekatan penelitian kualitatif yaitu menggambarkan atau melukiskan keadaan subjek dan objek,baik seseorang,lembaga dan masyarakat, dan lain sebagainya. Serta didasarkan atas hasil observasi yang dilaksanakan serta memberikan argumentasi terhadap apa yang ditemukan dilapangan dan dihubungkan dengan konsep teori yang relevan. (Sari, 2016). Dalam penelitian ini, peneliti berusaha memecahkan masalah dengan menggambarkan Kebijakan Parkir Kota Batam Dalam Meningkatkan Pendapatan Asli Daerah. Fokus penelitian ini evaluasi peraturan daerah Nomor 1 tahun 2012 tentang Penyelenggaraan dan Retrinusi Parkir dan evaluasi perda ini nanti akan didapat faktor pendukung faktor penghambat penerimaan Optimasi penyelenggaraan dan retribusi parkir di Kota Batam. Lokasi penelitian UPTD Parkir Kota Batam, DPRD Kota Batam dan Kecamatan Batam Kota. Teknik pengumpulan data adalah melalui purposive sampling, karena mengutamakan kualitas data yang diperoleh melalui penyampaian informan terkait dengan masalah penelitian (Yandra, 2017). Teknik analis datanya reduksi data, penyajian data dan penarik kesimpulan.

\section{HASIL DAN PEMBAHASAN}

Dalam berbagai literatur terdapat begitu banyak variasi definisi kebijakan publik dan terkesan tidak Seragam dan seringkali membingungkan masyarakat untuk memahaminya. Menurut buku Kamus Administrasi Publik(Keban,2008) public policy adalah pemanfaatan yang strategi terhadap sumberdayasumberdaya yang ada untuk memecahkan masalah masalah publik atau pemerintah.William N.Dunn (1994) dalam (Pasolong, 2011) Mengatakan bahwa kebijakan publik adalah suatu rangkaian pilihanpilihan yang saling berhubungan yang dibuat oleh lembaga atau pejabat pemerintah pada bidangbidang yang menyangkut tugas pemerintahan, seperti pertahanan keamanan,energi,kesehatan,pendidikan, kesejahteraan masyarakat,kriminalitas, perkotaan dan lain-lain. Kebijakan publik secara sederhana adalah konsep dasar rencana pemerintah atau organisasi publik untuk Mengatur kepentingan umum atau orang banyak.Sedangkan secara umum, pengertian kebijakan publik adalah segala sesuatu yang dikerjakan dan tidak dikerjakan oleh pemerintah untuk kepentingan umum. Segala sesuatu yang dimaksud adalah setiap aturan dalam kehidupan bersama, baik itu hubungan antar warga maupu warga dengan pemerintah.(Hernimawati,Dailiti, \& Sudaryono, 2017)

Menurut Dunn dalam Nugroho,evaluasi merupakan salah satu tingkatan di dalam proses kebijakan. Evaluasi adalah suatu cara untuk menilai apakah suatu kebijakan atau program itu berjalan dengan baik atau tidak. Berikut kutipan Nugroho tentang pengertian evaluasi menurut Dunn: Secara umum istilah evaluasi dapat disamakan dengan penaksiran (appraisal), pemberian angka (rating),dan penialian (assessment), kata-kata yang menyatakan usaha untuk menganalisis hasil kebijakan dalam arti satuan nilainya. Dalam arti yang lebih spesifik, evaluasi berkenaa dengan produksi informasi mengenai nilai atau manfaat hasil kebijakan. (Nugroho, 2011) Evaluasi kebijakan bisa meliputi tahap perumusan masalah kebijakan, implementasi, maupun tahap dampak kebijakan (Winarno, 2014). Suharto dalam kajiannya tentang pelayanan sosial, mengatakan evaluasi adalah diarahkan kepada keluaran (output), hasil (outcomes), dan dampak (impacts) dari pelaksanaan rencana stategis. Oleh karena itu,dalam pelaksanaan yang transparan dan akuntabel dan harus disertai dengan penyusunan sosial kinerja pelaksanaan rencana yang sekurang-kurangnya meliputi: (1)masukan,(2)keluaran dan (3)hasil. Jika dilihat dari pentahapannya, secara umum evaluasi dapat dibagi menjadi tiga jenis, yaitu: 
1. Evaluasi tahap perencanaan

Yaitu evaluasi yang digunakan dalam tahap perencanaan untuk mencoba memilih dan menentukan skala prioritas terhadap berbagai alternatif dan kemungkinan terhadap cara pencapaian tujuan yang ditetapkan sebelumnya.

2. Evaluasi pada tahap pelaksanaan Pada tahap ini evaluasi adalah suatu kegiatan yang melakukan analisa untuk menentukan tingkat kemajuan pelaksanaan dibanding dengan rencana. Terdapat perbedaan antara konsep menurut penelitian ini dengan monitoring. Evaluasi bertujuan terutama untuk mengetahui apakah yang ingin dicapai sudah tepat dan bahwa program tersebut direncanakan untuk dapat mencapai tujuan tersebut. Sedangkan monitoring bertujuan melihat pelaksanaan proyek sudah sesuai dengan rencana dan bahwa rencana tersebut sudah tepat untuk mencapai tujuan, sedangkan evaluasi melihat sejauh mana proyek masih tetap dapat mencapai tujuan, apakah tujuan tersebut sudah berubah dan apakah pencapaian program tersebut akan memecahkan masalah yang akan dipecahkan.

3.Evaluasi pada tahap pasca pelaksanaan Dalam hal ini konsep pada tahap pelaksanaan, yang membedakannya terletak pada objek yang dinilai dengan yang dianalisa, dimana tingkat kemajuan pelaksanaan dibanding rencana tetapi hasil pelaksanaan dibanding dengan rencana yakni apakah dampak yang dihasilkan oleh pelaksanaan kegiatan tersebut sesuai dengan tujuan yang akan atau ingin dicapai. (Suharto, 2006).

Retribusi adalah pungutan daerah sebagai pembayaran pemakaian atau karena jasa yang diberikan daerah. Dalam hal ini ada kekecualian tertentu, yaitu pembayaran yang dipungut oleh daerah sebagai penyelenggara perusahaan atau usaha yang dianggap sebagai perusahaan tidak dimaksudkan sebagai retribusi daerah(Samudra, 1995). Dalam teroi lain menyebytkan retribusi daerah adalah pungutan daerah sebagai pembayaran atas jasa atau pembeiran izin tertentu yang khusus disediakan dan/ atau diberikan oleh pemerintah daerah untuk kepentingan orang pribadi atau badan (Yani, 2002). Atas izin yang diberikan oleh Pemerintah, masyarakat selaku pengguna retribusi harus membayar atas yang telah Ia dapatkan. Menurut Banister, pemungutan biaya akan parkir mobil merupakan salah satu cara untuk meningkatkan kesadaran akan biaya sosial atas menggunakan mobil di daerah perkotaan yang padat. Salah satu mekanisme pemungutan tersebut akan menghubungkan biaya dari tempat parkir ke tingkat kantor daerah dan ke tingkat sewa. Ada dua pendekatan untuk menganalisis kriteria keadilan, yaitu:

1. Benefit Principle (Prinsip Manfaat)

2. Ability to Pay (Prinsip Kemampuan

a. Membayar)

b. Ada empat prinsip umum yang dapat digunakan sebagai indikator dalam pengenaan retribusi, yaitu: kecukupan, keadilan, kemudahan administrasi dan kepatian hukum

Berdasarkan hasil temuan data peneliti di lapangan bahwa kebijakan parkir Kota Batam dalam meningkatkan PAD optimasinya masih jauh dari capaian target. Dengan demikian perlu ada kebijakan baru dari Pemerintah Kota Batam agar ada perubahan dalam pencapaian target realisasi tersebut. Dalam RanPerda (Rancangan Peraturan Daerah Kota Batam) Perubahan Atas Peraturan Daerah Nomor 1 Tahun 2012 Tentang Penyelenggaraan Dan Retribusi Parkir mengatakan bahwa Perda (Peraturan Daerah) Kota Batam Nomor 1 Tahun 2012 sudah ada, RanPerda ini dibuat atas usulan Pemerintah Kota, dibuat atas dasar:

1. Ingin merubah tarif

2. Ingin adanya perubahan sistem di dalam khususnya perparkiran

3. Adanya peningkatan fasilitas bagi pengguna parkir itu sendiri,perlindungan termasuk asuransi dan lain sebagainya

4. Sistem bayar yang berlangganan atau sistem tidak berlangganan

5. Perubahan dari pengelola Parkir Perubahan Perda No.1 Tahun 2012 Tentang Penyelengaraan dan Retribusi parkir ini adalah usulan dari Pemerintah Kota Batam agar memperbaiki pengelolaan 
parkir di Kota Batam. Artinya selama ini,ditenggarai pengelolaan penyelenggraan dan retribusi parkir di Kota Batam memang diperlukan terobosan perubahan agar dapat menambah PAD Kota Batam. Selama ini dari data 6 tahun terakhir potensi parkir belum tercapai secara optimal.Temuan angka-angka realisasi penerimaan retribusi parkir dalam 6 tahun terakhir dapat dilihat dalam tabel berikut ini :

Tabel 2. Realisassi Penerimaan Retribusi Parkir 6 Tahun Terakhir

\begin{tabular}{|l|l|l|l|l|l|}
\hline No. & Tahun & Target & Realisasi & Pencapaian & Keterangan \\
\hline 1. & 2011 & 1.400 .000 .000 & 1.400 .000 .000 & $100 \%$ & Swakelola/Penunjukan \\
\hline 2. & 2012 & 5.261 .350 .000 & 3.428 .414 .000 & $65,16 \%$ & $\begin{array}{l}\text { Pihak Ketiga \& UPT } \\
\text { Pelayanan parkir } \\
\text { (Terhitung Sept 2012) }\end{array}$ \\
\hline 3. & 2013 & 4.500 .000 .000 & 3.296 .835 .000 & $73,26 \%$ & $\begin{array}{l}\text { UPTD Pelayanan } \\
\text { Parkir }\end{array}$ \\
\hline 4. & 2014 & 3.312 .000 .000 & 3.594 .000 .000 & $108,51 \%$ & $\begin{array}{l}\text { UPTD Pelayanan } \\
\text { Parkir }\end{array}$ \\
\hline 5. & 2015 & 6.000 .000 .000 & 3.669 .383 .000 & $61,16 \%$ & $\begin{array}{l}\text { UPTD Pelayanan } \\
\text { Parkir }\end{array}$ \\
\hline 6. & 2016 & 3.855 .571 .200 & 3.605 .583 .000 & $93,52 \%$ & UPTD Pelayanan \\
\hline 7. & 2017 & & & & \\
\hline
\end{tabular}

Sumber:UPTD Pelayanan Parkir Kota Batam

Berikut tampilan data dikota Batam jumlah volume kendaraan sejak tahun 2015 dimulai dari bulan Juli sampai Desember:

Tabel 3. Jumlah Kendaraan Bermotor Yang Wajib Uji

Menurut Jenis Kendaraan Tahun 2015

\begin{tabular}{|l|l|l|l|l|l|l|l|}
\hline No & $\begin{array}{l}\text { Jenis } \\
\text { Kendaraan }\end{array}$ & Juli & Agustus & September & Oktober & November & Desember \\
\hline 1. & Taksi & $\mathbf{2 . 5 0 7}$ & $\mathbf{2 . 5 0 7}$ & $\mathbf{2 . 5 0 7}$ & $\mathbf{2 . 5 0 7}$ & $\mathbf{2 . 5 0 7}$ & $\mathbf{2 . 5 0 7}$ \\
\hline & Umum & 2.507 & 2.507 & 2.507 & 2.507 & 2.507 & 2.507 \\
\hline 2. & Oplet & $\mathbf{1 . 7 3 7}$ & $\mathbf{1 . 7 3 7}$ & $\mathbf{1 . 7 3 7}$ & $\mathbf{1 . 7 3 7}$ & $\mathbf{1 . 7 3 7}$ & $\mathbf{1 . 7 3 7}$ \\
\hline & Umum & 1.737 & 1.737 & 1.737 & 1.737 & 1.737 & 1.737 \\
\hline 3. & Bis & $\mathbf{2 . 9 5 0}$ & $\mathbf{2 . 9 5 9}$ & $\mathbf{2 . 9 6 8}$ & $\mathbf{2 . 9 8 2}$ & $\mathbf{3 . 0 0 0}$ & $\mathbf{3 . 0 0 4}$ \\
\hline & Umum & 786 & 789 & 789 & 790 & 798 & 800 \\
\hline & Bukan Umum & 2.107 & 2.113 & 2.120 & 2.133 & 2.143 & 2.145 \\
\hline & Pemerintah & 57 & 57 & 59 & 59 & 59 & 59 \\
\hline 4. & Kend.Barang & $\mathbf{2 0 . 0 5 9}$ & $\mathbf{2 0 . 2 4 1}$ & $\mathbf{2 0 . 3 6 6}$ & $\mathbf{2 0 . 5 2 5}$ & $\mathbf{2 0 . 6 7 9}$ & $\mathbf{2 0 . 8 1 8}$ \\
\hline
\end{tabular}




\begin{tabular}{|l|l|l|l|l|l|l|l|} 
& Umum & 435 & 443 & 447 & 464 & 473 & 498 \\
\hline & Bukan Umum & 19.383 & 19.545 & 19.665 & 19.807 & 19.952 & 20.057 \\
\hline & Pemerintah & 241 & 253 & 254 & 254 & 254 & 263 \\
\hline 5. & $\begin{array}{l}\text { Truck } \\
\text { Tempelan }\end{array}$ & $\mathbf{8 5 6}$ & $\mathbf{8 5 6}$ & $\mathbf{8 5 6}$ & $\mathbf{8 5 6}$ & $\mathbf{8 5 6}$ & $\mathbf{8 5 6}$ \\
\hline & Umum & 63 & 63 & 63 & 63 & 63 & 63 \\
\hline & Bukan Umum & 793 & 793 & 793 & 793 & 793 & 793 \\
\hline & Pemerintah & & - & & & - & \\
\hline & Jumlah & $\mathbf{2 8 . 1 0 9}$ & $\mathbf{2 8 . 3 0 0}$ & $\mathbf{2 8 . 4 3 4}$ & $\mathbf{2 8 . 6 0 7}$ & $\mathbf{2 8 . 7 7 9}$ & $\mathbf{2 8 . 9 2 2}$ \\
\hline
\end{tabular}

Sumber: Dinas Perhubungan Kota Batam

Dari hasil penelitian dapat dijelaskan bahwasannya target pencapaian retribusi parkir masih rendah,walaupun,secara pencapaian hampir memenuhi target,namun jika dilihat dari berbagaipotensiareaparkir di Kota Batam, seharusnya pencapaian angkanya bisa jauh dari target yang ada.Potensi tersebut tidak hanya dilihat dari banyaknya titik parkir di Kota Batam yang belum digarap, tapi juga dapat dilihat dari sektor volume kendaraan di Kota Batam memang mengalami peningkatan dari tahun ke tahun.

Tidak dapat dipungkiri banyaknya jumlah volume kendaraan yang terus berkembang mempengaruhi pendapatan retribusi parkir di Kota Batam.Dari data tersebut jumlah kendaraan di Kota Batam diperkirakan memiliki potensi pencapaian estimasi target 30 Miliar di tahun 2017.Berdasarklan hasil penelitian, kenaikan tarif sebesar 100 persen yang diajukan oleh Dinas Perhubungan Kota Batam,perlu ditinjau ulang kembali dan harus melalui pertimbangan yang matang.Target pendapatan parkir pemerintah Kota Batam pada tahun 2015 adalah sebesar 6 Miliar, namun yang realisasi hanya sekitar Rp 3,8 miliar. Alasan kenaikan tarif parkir harus ditinjau secara akademis,peninjauannya juga terkait dengan apakah potensi yang dulu sudah optimal atau belum. Jangan Ranperda yang diajukan oleh pemerintah kota ini menciptakan peluang baru untuk menciptakan hilangnya potensi pendapatan parkir semakin besar. Dengan kenaikan tarif 100 persen dan jumlah kendaraan di Kota Batam hampir mencapai 765 ribu unit, berpotensi melebihi angka 36 Miliar.Kalau proyeksi pendapatannya tetap berkisar 3,8M saja,ada kekuatiran malah ada dugaan ada pihak yang tidak bertanggung jawab.Kenaikan tarif 100 persen yang diajukan oleh Pemerintah Kota Batam di satu sisi memang kenaikan tarif Mampu mengdongkrakpendapatanPAD,namun disisi lain bahwa kenaikan tarif parkir tidak serta mertamenyelesaikan persoalan,sebabada kebijakan-kebijakan lain atau opsi lain selain menaikkan tarif parkir tersebut. Hal itu dilakukan demi mengoptimalkan potensi yang ada dahulu.Jangan kemudian kenaikan tarifini dilakukan,akan tetapi tidak dibarengi dengan berbagai macam perbaikan diberbagai segala aspek. Pengelolaan dan retribusi parkir ini memang kompleks dan rumit,persoalan kenaikan ini masih debatabledibahas antara Dinas Perhubungan Kota Batam dengan DPRD,perbedaan pendapat antara Dinas Perhubungan dengan DPRD Kota Batam soal kenaikan tarif belum ada titik temu.Masalah Peraturan Daerah Kota BatamNomor 1 Tahun 2012 dalam penyelenggaraan dan retribusi parkir sebenarnya terdapat pada SDM. Oleh karena itu, perlu dilakukan sebuah kajian secara transparan yang melibatkan akademisi untuk memberikan masukan-masukan strategis persoalan masalah retribusi parkir di Kota Batam.Persoalan SDM (Sumber DayaManusia) di level lapangan memang meruapakan masalah klasik yang sampai sekarang masih perlu ditinjau ulang lagi kebijakannya, kemudian ada persoalan sistem yang dijalani selama ini masih banyak kekurangan dari berbagai hal sehingga capaiannya cuma 1/10 dari optimasi yang diharapkan. Sudah hampir 10 tahun pencapaian hasil retribusi parkir masih kisaran angka dari 2 Miliar. Jika dari angka 2 sampai 3 Miliar saja terjadi kebocoran 
bagaimana dengan realisasi target mencapai angka 30 Miliar, dapat diasumsikan prediksi potensi bocornya semakin besar.

Kebijakan Kota Batam dalam mengadopssi parkir berlangganan,prototipe percontohannya menginginkan seperti Kabupaten Sidoarjo. Hanya saja persolannya, tidak dapat diterapkan karena masalah SDMyang belum mumpuni untuk menerapkan sistem parkir berlangganan, dan juga tidak ada keharusan untuk menerapkannya karena parkir berlangganan termasuk retribusi bukan pajak. SDM di Kota Batam belum mampu memenuhi espektasi tersebut, SDM nya sebetulnya perlu dibina, difasilitasi dan diberikan semacam pelatihan dan diklat (pendidikan dan pelatihan) sehingga memahami cara bagaimana memaksimalkan menaikan angka retribusi parkir.

Perubahan pengelola parkir di Perda yang lama juga mengalami perubahan, dahulu kerja sama dengan swasta, hari ini dari Ranperda yang baru tentang perubahan atas peraturan daerah nomor 1 Tahun 2012 Tentang Penyelenggaraan dan retribusi parkir membentuk UPTD. Ranperda ini belum selesai dan masih diperpanjang lagi. Ada beberapa pasal yang masih debatable dalam penyesuaian tarifnya. Pemerintah Kota Batam ingin langsung menaikkan tarif Rp.2000,- menjadi ke Rp. 4000 dan dari Rp.1000 berubah ke Rp 2000, artinya kenaikannya mencapai 100 persen. DPRD sebagai lembaga mitra pemerintah tidak mau adanya kenaikan dan ingin bertahan pada tarif lama, karena potensinya itu belum optimal.

Faktor Penghambat Penerimaan Optimasi Penyelenggaraan dan Retribusi Parkir Di Kota Batam

1. Sistem Pengelolaan Fasilitas

Parkir Batam Yang Belum Memadai Terkait tata kelola parkir di Kota Batam, memang masih jauh dari prinsip transparansi,sesuai UU keterbukaan informasi publik, semua masyarakat berhak meminta informasi, termasuk pengelolaan anggaran apapun yang memang bersentuhan dengan masyarakat dan informasi yang wajib dan berhak diterima oleh masyarakat. Menurutnya, Pemerintah Kota Batam harus terbuka terkait sistem pengelolaan dan sistem pelayanan parkir yang diterapkan. Selama ini pemerintah Kota Batam dinilai belum terbuka terhadap siapa saja yang mendapat hak untuk mengelola parkir di tepi jalan umum, termasuk prosedur dan persyaratan yang harus dipenuhi. Sekarang ini pelayanan parkir ada sumber tapi tidak ada pengawasan. Akibatnya Pendapatan Asli Daerah (PAD) dari retribusi parkir selalu di bawah target. Percumaretribusinya dinaikkan jika pengelolaannya tidak diperbaiki.

2.Belum Tedapat Indeks Kepuasan Publik

Untuk mengukur kepuasan publik dalam sistem pengelolaan parkir harus dilakukan dengan indeks survei kepuasan publik. Sampai saat ini, indeks kepuasan publik belum dibuat atau survei itu belum ada. Dalam Perda No.1 Tahun 2012 ini memang belumlengkap, maka harus ada penyempurnaan perubahan. Perda yang lama pelayanan prima itu memang belum ada. Dan dengan Ranperda baru ada jaminan asuransi dan sebagainya, dan tertulis dan harus dilaksanakan.

3.Kinerja Sumber Daya Manusia Belum Efektif

Kendala dalam pengelolaan dan retribusi parkir ini adalah soal SDM. Sumber Daya Manusia ditenggarai tidak mampu bekerja sesuai dengan apa yang telah diharapkan, realisasi di lapangan cuma 2,3 Miliar, padahal potensinya bisa mencapai 30 Miliar.

Penyebab dugaannya bisa jadi kebocoran dan ketidakefektifan kinerja. Dengan realisasi yang sangat kecil dan jauh dari pada target. Dapat disimpulkan SDMnya tidak mampu menggali optimasi dari apa yang seharusnya. Optimasi tidak tercapai dan kinerja nya jauh di bawah optimal. SDM itu tidak mampu menterjemahkan kinerja yang optimal. Persoalan SDM ini merupakan pekerjaan rumah bagi Dinas Perhubungan Kota Batam.

\section{Faktor Pendorong Penerimaan Optimasi Penyelenggaraan dan Retribusi Parkir Di Kota Batam}

1.Pelayanan Prima Dan Kemudahan Administrasi Bagi Pengguna Parkir Kota Batam Perbaikan pelayanan parkir merupakan keharusan yang dilakukan oleh Dinas Perhubungan Kota Batam. Hasil temuan di lapangan belum ditemukan kewajiban penyelenggara untuk mengganti kerugian, kehilangan 
dan kerusakan kendaraan saat di parkir. Sejauh mana komitmen pemerintahdaerahuntukmerealisasikan fasilitas yang direncanakan ini.

2. Menggunakan Sistem Elektronik

(Online)

Pemerintah memberikan fasilitas parkir adalah dengan sistem elektronik. Sistem diubah dari manual ke elektronik, akan ada sistem langganan yang nantinya dipungut bekerja sama dengan Samsat saat membayar pajak kendaraan bermotor. Dengan sistem elektronik maka beban pengeluaran semakin murah, lebih terukur, akuntabilitas dan memperkecil kehilangan potensi pendapatan. Dengan sistem online, masyarakat yang membayar akan langsung terdata secara online, masyarakat yang membayar akan langung terdata secara realtime di sistem, mulai dari jumlah, tanggal, jam bahkan menit pembayarannya, seperti apa yang sudah dipercontohkan Kota Jakarta, Bandung dan Surabaya.

\section{KESIMPULAN}

Berdasarkan hasil analisis datayang dilakukan peneliti untuk menjawab persoalan, selanjutnya dapat ditarik kesimpulan dari hasil penelitian yang berjudul kebijakan parkir Kota Batam dalam meningkatkan PAD adalah sebagi berikut:

Pertama, bahwa kebijakan parkir Kota Batam melalui Perda No.1 Tahun 2012 tentang penyelenggaraan dan retribusi parkir belum optimaldalam pencapaian target dan realisasinya. Padahal berdasarkan data, potensi parkir di Kota Batam dapat jauh melebih target sesuai dengan potensi patkir jika dapat dikelola dengan baik. Data yang di dapat dari UPTD parkir dari target parkir masih minim, dan realisasinya pun juga juga tidak begitu signifikan, kecenderungannya stagnan dan belum menunjukkan perubahan dalam peningkatan PAD di Kota Batam.

Kedua, Adapun faktor-faktor belum optimalnya penerimaan pajak di Kota Batam disebabkan: Sisstem pengelolaan fasilitas parkir yang belum layak, Indeks kepuasan publik tidak diimplementasikan, kinerja SDM belum efektif, ada yang gagal dalam sistem pengelolaan parkir Kota Batam.

Ketiga, Adapun faktor-faktor yang mendukung penerimaan pajak di Kota Batam disebabkan: pelayanan prima dan kemudahan adminsitrasi bagi pengguna parkir, Kekuatan leadershipdari Pemerintah Kota Batam, Optimalisasi fungsi dan tugas dari UPTD Kota Batam, prinsip akuntablitas dan transparansi dalam pengelolaan parkir.

\section{SARAN}

Sayangnya dalam penyelenggaraan dan retribui parkir potensinya digali dulu, jangan tiba-tiba dinaikkan menyebabkan celah untuk parkir tidak optimal. Dengan ada UPTD ini, Pemerintah Kota Batam diharapkan bisa melakukan seperti di Kabupaten Sidoarjo, sebab di Kabupaten Sidoarjosudah mengarah pada parkir berlangganan dengan menggunakan Peraturan Gubernur. UPTD secara khusus mengelola parkir, harapannya kemudian dengan adanya instansi UPTD ini dapat lebih fokus mendongkrak PAD Kota Batam yang selama ini penyerapan anggarannya masih jauh dari target penerimaan PAD. 


\section{DAFTAR PUSTAKA}

[1]. Davey,K.(1988).PembiayaanPemerintahDaerah:Praktek-PrakteInternasional Dan Relevansinya Bagi Dunia Ketiga.Jakarta: UI Press.

[2]. Hernimawati, Dailiti, S., \& Sudaryono.(2017). Agenda Kebijakan Publik Pada Badan Perpustakaan Dan Arsip (BPA)Kota Pekanbaru Niara, 10(1), 7-19

[3] Keban, Y. T. (2008). Enam DimensiStrategis Administrasi Publik. Jogjakarta: Gavamedia.

[4]. Nugroho, R. (2011).Dinamika Kebijakan Analisis Kebijakan Manajemen Kebijakan. Jakarta:PT.Elex Media Komputindo.

[5]. Pasolong, H. (2011). Teori Administrasi Publik. Bandung: Alfabeta.

[6]. Pratama.(2015).Analisis TerhadapImplementasi Kebijakan RetribusiParkir Berlangganan Di Kota Batam. Universitas Indonesia.

[7]. Samudra, A. A. (1995). Perpajakan Di Indonesia, Keuangan, Pajak, Dan Retribusi. Jakarta: Gramedia Pustaka Utama.

[8]. Sari,F. M. (2016). Analisis Pelaksanaan Program Konversi Minyak Tanah Ke Gas. Niara, 8(2), 1421.

[9]. Suharto, E. (2006). Analisis Kebijakan Publik, Edisi Revisi. Bandung: Alfabeta.

[10]. Winarno. (2014). Kebijakan Publik (Teori, Proses Dan Studi Kasus). Jakarta: Center Of Academic Publishing.

[11]. Sufi, W., \& Saputra, T. (2017). Implementation of village empower program in supporting form of institutions of village business institutions (BUMDes)(Study on Dayang Suri Village Bungaraya Sub District Siak Regency Riau Province). Jurnal Perspektif Pembiayaan dan Pembangunan Daerah, 5(2), 91-98.

[12]. Yandra, A. (2017). Fisibilitas Pilkada Serentak Tahap II Kota Pekanbaru Pasca Permendagri No 18 Tahun 2015 , 9(18), 62-74.

[13]. Yani, A. (2002). Hubungan Keuangan Antara PemerintahPusat Dan Daerah Di Indonesia. Jakarta: Raja Grafindo Persada 